UDC 575:639.3

\title{
THE GENETIC STRUCTURE OF DIFFERENT AGE GROUPS OF SILVER AND BIGHEAD CARPS FROM FISH FARM LIMANSKE
}

T. Nagorniuk, achtaan@ukr.net, Institute of Fisheries NAAS, Kyiv

I. Hrytsyniak, info@ifr.com.ua, Institute of Fisheries NAAS, Kyiv

N. Borysenko, b natalia@i.ua, Institute of Fisheries NAAS, Kyiv

Purpose. Studying the peculiarities of the genetic structure of different age groups of silver and bighead carps from fish farm Limanske with the use of genetic-biochemical markers.

Methodology. The methods of vertical polyacrylamide and horizontal starch electrophoresis with our own modifications have been used for the study. Sampling of the biological material and histochemical staining of gel plates were carried out using the generally accepted methods. Statistical analysis of the obtained data were performed in "Biosys-I".

Findings. We analyzed the genetic structure of age-1, age-1+ and age-2 of silver and bighead carps with the use of genetic-biochemical markers - Pralb, EST, MDH, ME, CA. We demonstrated the peculiarities of allele frequencies and genotypic composition of protein system loci. A high level of heterozygosity in the examined was detected loci for age-1 silver carp - 66.7-88.9\% and age-1 bighead carp - 65.4-77.8\%. A significantly higher level of the observed average heterozygosity compared to the expected heterozygosity of age-1 as silver carp ( $\mathrm{Ho}=75.9 \%$, $\mathrm{He}=49,6 \%$ ), and bighead carp ( $\mathrm{Ho}=73,6 \%, \mathrm{He}=47,9 \%)$ was observed. This fact indicated on the necessity for performing a stabilization of their genetic structure. The calculated Wright's F index in different age groups showed a predominance of the observed level of the average heterozygosity over the expected one for $22.7-53 \%$ in silver carp and $24.5-53.7 \%$ in bighead carp. A stabilization of the genetic structure in age-2 silver carp ( $\mathrm{Ho}=57.8 \%$; $\mathrm{He}=47.1 \%$ ) by the heterogeneity level was observed.

Originality. For the first time we analyzed the genetic structure and the level of heterogeneity of the breeding groups of age-1, age-1+, age-2 silver and bighead carps from fish farm Limanske with the use of genetic-biochemical markers.

Practical value. The results of the study can be used in selection and breeding works aimed at creating the breeding stocks of silver and bighead carps to control the level of interspecies genetic variability. The obtained experimental data of the genetic structure analysis of silver and bighead carps of different age groups will be used for the monitoring of the genetic structure changes during their adaptation to new environmental conditions.

Key words: silver carp, bighead carp, age-1, age-1+, age-2, genetic-biochemical markers, genetic structure, alleles, genotype, heterozygosity.

\section{PROBLEM STATEMENT AND ANALYSIS OF LAST ACHIEVEMENTS AND PUBLICATIONS}

An important task of selective-breeding works in aquaculture is conservation and improvement of the genetic pool of culture fish species [1,2]. Provision of aquaculture enterprises with high quality fish seeds of Chinese carps requires continuous genetic control, which allows detecting species-specific properties of genetic pools and studying the mechanisms of their formation, peculiarities of gene drifts from the ancestral genetic pool to the existing specific fish group, the effects of different reproduction conditions. The fundamental of such works are genetic studies, which showed that the brood stocks of silver carp were crossbreeds of Amur and Chinese races, which also contained admixtures of interspecies hybrids of silver and bighead

ISSN 2075-1508 РИБОГОСПОДАРСЬКА НАУКА УКРАЇНИ • № 2/2015

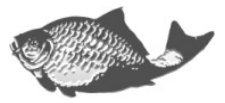


carps. Ignoring the importance of selective-breeding works when exploring new breeding objects as well as the lack of control when forming brood stocks of acclimatized species resulted in excessive hybridization degree and reduction of brood fish fecundity [2]. Therefore, the primary task in the reproduction of Chinese carps is the restoration of the genetic purity of each species and solution of the problem of genetic diversity conservation within each species [2]. Conservation of the genetic diversity of agricultural animals at sufficiently high level is also one of important tasks for effective selective works aimed at increasing the adaptability of breeds [3].

A number of authors described different types of molecular-genetic markers, which were found to be essential for the genetic monitoring of breed stocks of fish, for detecting the range of population and specific variability, studying phylogenesis, the degree of genetic similarity and further microevolution of species [4]. Some researchers point at the possibility of using the fractional composition of albumin and transferrin as biochemical markers in genetic monitoring of brood stocks for reducing the effect of negative consequences of artificial reproduction on the genetic structure of silver and bighead carps $[5,6]$. Other researchers working in the field of the use of proteins and isozymes studied the genealogic diversity of Amur and Chinese lines of silver carp, which differ by the frequency of erythrocyte glucose-6-phosphate dehydrogenase [7]. They compared the genotypic composition of the protein systems of silver carp of Vietnamese and Chinese origins that allowed establishing the species specificity of superoxide dismutase locus [8]. Some literature sources indicate on age-related and wedge variability of the frequency of protein loci alleles in silver carp. It was noted that such changes were related to the adaptation to culture conditions and occurred under the control of not only artificial but also natural selection [9]. The peculiarities of the genetic variability of different Chinese carp species with the use of microsatellite markers were studied [10]. Currently, molecular-genetic studies of Ukrainian population of Chinese carps are fragmentary. An analysis of the variability of the genetic structures and establishment of species-specific peculiarities of Ukrainian populations of Chinese carps with the used of microsatellite loci was performed [11, 12]. The works on the study of biochemical marker polymorphism and heterogeneity of Ukrainian populations of Chinese carps in breeding aquaculture facilities in Ukraine are continued $[13,14]$.

\section{HIGHLIGHT OF THE EARLIER UNRESOLVED PARTS OF THE GENERAL PROBLEM. AIM OF THE STUDY}

Forming the purebred breeding stocks of silver and bighead carps requires continuous genetic control at different age stages. Hence, one of important problem in aquaculture is an assessment of the genetic structure of breeding stocks of different fish culture objects.

The aim of the study was to study the peculiarities of the genetic structures of multiple-age silver and bighead carps with the use of genetic-biochemical systems.

\section{MATERIALS AND METHODS}

For genetic structure studies, we used blood samples of silver (Hypophthalmichthys molitrix) and bighead (Aristichthys nobilis) carps reared in the conditions of fish farm 
Limanske, Kharkiv region: silver carp - age-1 $(n=30)$, age-1+ $(n=35)$, age-2 $(n=30)$; bighead carp - age-1 $(n=27)$, age $1+(n=30)$, age-2 $(n=30)$.

Blood samples were taken from live fish from the caudal vein into plastic tubes with heparin. They were centrifuged at $3000 \mathrm{rpm}$ for $10 \mathrm{~min}$. Different blood fractions were placed into separate tubes and stored at a temperature of $-20^{\circ} \mathrm{C}$.

Following genetic-biochemical markers were analyzed: loci of prealbumin (Pralb), esterase (EST, EC 3.1.1.1), malate dehydrogenase ( $M D H, E C$ 1.1.1.37), malic enzyme (ME, EC 1.1.1.40), and carbonic anhydrase (CA, EC 4.2.1.1).

During the study, we used the methods of the vertical polyacrylamide and horizontal starch electrophoresis $[15,16]$ with in-house modifications and following histochemical staining [17] and genotyping according to recommendations [5]. Calculations of allele frequencies, genotype ratios, observed $\left(H_{o}\right)$ and expected $\left(H_{e}\right)$ heterozygosity, Wright's Fixation Index were performed in "Biosys-1" program [18, 19].

\section{STUDY RESULTS AND THEIR DISCUSSION}

The performed analysis of the genetic structures of silver and bighead carps with the use of genetic-biochemical markers allowed detecting certain peculiarities of the frequency distribution of allele variants in multiple-age groups of these species (Table $1)$.

The prevalence of the frequency of the fast migrating allele variant $M e F$, compared to slow migrating $M e S$, was observed in age-1+ and age- 2 of both species. As for Pralb locus, age-1 and age-1+ bighead carp differed from age-2 silver carp by a higher frequency of Pralb $A$ allele ( 0.635 and 0.650 , respectively). EST locus in age-1+ silver carp was represented by a higher frequency of Est $F-0.618$ that was different from age-1+ fish, in which this allele occurs with a lower frequency Est $F-0.365$ (Table 1).

The distribution of heterozygous genotypes in the studied groups indicates on significant difference of age-1 fish from other age groups due to the excess of heterozygous fish for all examined loci in silver (except Pralb locus) and bighead carps, $\mathrm{P}<0.001-0.05$ (Table 2).

In age-1+ fish, there is an increase in the number of loci, which were in equilibrium state. E.g., we detected a significant prevalence of fish with heterozygous genotypes in silver carp for $E S T, M E$ and $C A$ loci $\mathrm{P}<0.001-0.05$, while only EST locus in bighead carp, $\mathrm{P}<0.01$.

In age-2 fish samples, we did not detect significant differences between the distribution of observed and expected heterozygotes for all loci except $C A(\mathrm{P}<0.05)$ in silver carp as well as EST $(\mathrm{P}<0.01)$ and Pralb $(\mathrm{P}<0.05)$ in bighead carp (Table 2).

The selection of fish with the best biological-technical parameters contributed to significant prevalence of heterozygous genotypes in age-1 fish of both species.

The performed analysis of heterozygosity and genetic variability according to Wright's F-statistics demonstrated the degree of the difference between observed and expected levels of heterozygosity (Fig. 1,2). 
THE GENETIC STRUCTURE OF DIFFERENT AGE GROUPS

OF SILVER AND BIGHEAD CARPS FROM FISH FARM LIMANSKE

Table 1. Allele frequencies by genetic-biochemical markers

\begin{tabular}{|c|ccc|c|c|c||}
\hline \multirow{2}{*}{ Loci } & \multicolumn{3}{|c|}{ Silver carp } & \multicolumn{3}{c||}{ Bighead carp } \\
\cline { 2 - 7 } & Age-1 & Age-1+ & Age-2 & Age-1 & Age-1+ & Age-2 \\
\hline Pralb $(n)$ & 30 & 34 & 30 & 26 & 30 & 30 \\
$A$ & 0,533 & 0,456 & 0,317 & 0,635 & 0,650 & 0,533 \\
$B$ & 0,467 & 0,544 & 0,683 & 0,365 & 0,350 & 0,467 \\
EST $(n)$ & 27 & 34 & 29 & 26 & 29 & 29 \\
$F$ & 0,444 & 0,618 & 0,569 & 0,365 & 0,517 & 0,534 \\
$S$ & 0,556 & 0,382 & 0,431 & 0,635 & 0,483 & 0,466 \\
MDH(n) & 29 & 35 & 30 & 27 & 30 & 30 \\
$F$ & 0,483 & 0,571 & 0,583 & 0,407 & 0,533 & 0,567 \\
$S$ & 0,517 & 0,429 & 0,417 & 0,593 & 0,467 & 0,433 \\
$M E(n)$ & 29 & 35 & 30 & 27 & 30 & 30 \\
$F$ & 0,517 & 0,614 & 0,667 & 0,574 & 0,600 & 0,633 \\
$S$ & 0,483 & 0,386 & 0,333 & 0,426 & 0,400 & 0,367 \\
$C A(n)$ & 29 & 35 & 30 & 27 & 30 & 30 \\
$F$ & 0,431 & 0,471 & 0,483 & 0,463 & 0,517 & 0,483 \\
$S$ & 0,569 & 0,529 & 0,517 & 0,537 & 0,483 & 0,517 \\
\hline \hline
\end{tabular}

Table 2. Distribution of heterozygous genotypes by loci in silver and bighead carps

\begin{tabular}{|c|c|c|c|c|c|c|c|}
\hline \multirow{2}{*}{ Loci } & \multirow{2}{*}{ Genotypes } & \multicolumn{3}{|c|}{ Silver carp } & \multicolumn{3}{|c|}{ Bighead carp } \\
\hline & & $G_{o}$ & $G_{e}$ & $\chi^{2}$ & $G_{o}$ & $G_{e}$ & $\chi^{2}$ \\
\hline \multicolumn{8}{|c|}{ Age-1 } \\
\hline EST & FS & 24 & $13,6^{* * *}$ & 16,497 & 19 & $12,3^{* *}$ & 8,097 \\
\hline$M D H$ & FS & 22 & $14,7^{* *}$ & 7,297 & 20 & $13,3^{* *}$ & 7,190 \\
\hline$M E$ & FS & 22 & $14,7^{* *}$ & 7,297 & 21 & $13,5^{* *}$ & 8,8 \\
\hline Pralb & $A B$ & 20 & 15,2 & 3,119 & 17 & $12,3 *$ & 3,987 \\
\hline$C A$ & FS & 21 & $14,5 *$ & 6,115 & 21 & $13,7^{* *}$ & 8,034 \\
\hline \multicolumn{8}{|c|}{ Age-1+ } \\
\hline EST & FS & 26 & $16,3^{* * *}$ & 12,456 & 22 & $14,7^{* *}$ & 7,297 \\
\hline$M D H$ & FS & 22 & 17,4 & 2,533 & 16 & 15,2 & 0,089 \\
\hline$M E$ & FS & 23 & $16,8^{*}$ & 4,867 & 18 & 14,6 & 1,635 \\
\hline Pralb & $A B$ & 17 & 17,1 & 0,002 & 17 & 13,9 & 1,577 \\
\hline$C A$ & FS & 25 & $17,7 *$ & 6,140 & 17 & 15,2 & 0,415 \\
\hline \multicolumn{8}{|c|}{ Age-2 } \\
\hline$E S T$ & FS & 19 & 14,5 & 2,942 & 23 & $14,7^{* *}$ & 9,636 \\
\hline$M D H$ & FS & 15 & 14,8 & 0,004 & 16 & 14,9 & 0,143 \\
\hline$M E$ & FS & 18 & 13,6 & 3,358 & 18 & 14,2 & 2,280 \\
\hline Pralb & $A B$ & 13 & 13,2 & 0,007 & 22 & $15,2^{*}$ & 6,249 \\
\hline$C A$ & FS & 21 & $15,2^{*}$ & 4,439 & 17 & 15,2 & 0,415 \\
\hline
\end{tabular}

Note: Go - observed genotypes; Ge - expected genotypes; * $\mathrm{P} \leq 0.05 ; * * \mathrm{P} \leq 0.01 ; * * * \mathrm{P} \leq 0.001$. 
The observed level of heterozygosity in age- 1 silver carp significantly exceeded the expected one for all loci: from $33.9 \%$ for Pralb to $80 \%$ for EST according to the Wright's Fixation Index ( $F$ from -0.339 to -0.8$)$. In age- $1+$ silver carp, $F$ values, which indicated significant prevalence of $H_{o}$ over $H_{e}$, were detected for all loci except Pralb (from $28.3 \%$ for $M D H$ to $61.9 \%$ for $E S T$ ). In age-2 silver carp, the significant difference between observed and expected heterozygosity was observed for $C A(40.2 \%), E S T$ $(33.6 \%)$, and $M E(35 \%)$ (Fig 1).

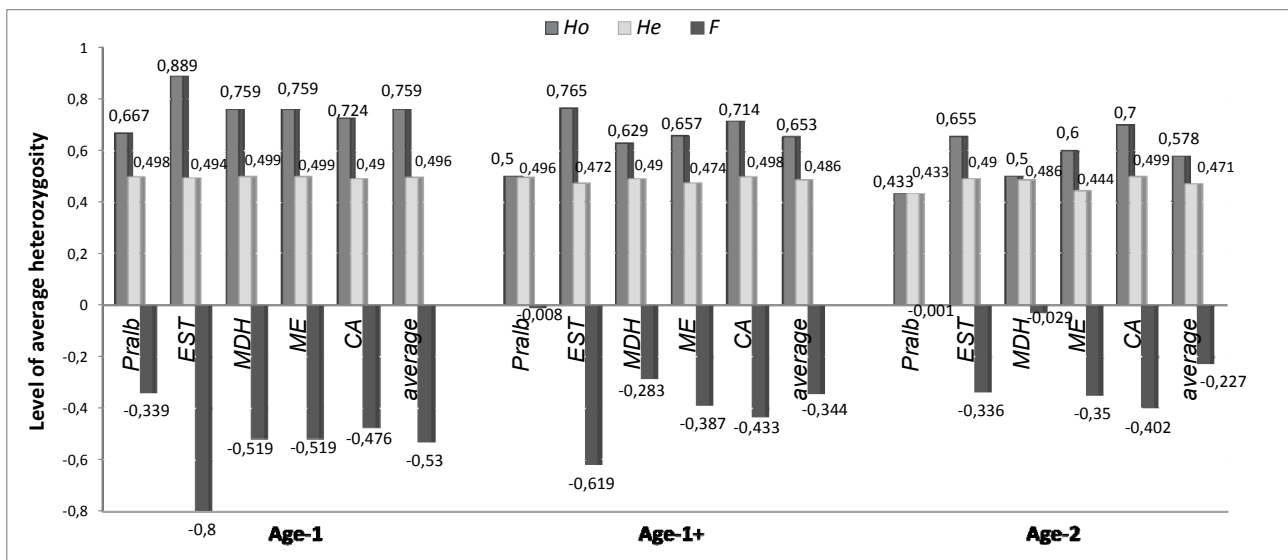

Fig. 1. The heterozygosity level and Wright's Fixation Index by geneticbiochemical markers in silver carp

Note: Ho - observed heterozygosity level; $\mathrm{He}$ - expected heterozygosity level; F - Fixation Index

In age-1 bighead carp, the observed heterozygosity level exceeded the expected one for all loci: from $41 \%$ for Pralb to $59 \%$ for $M E$ that reflected the calculated Wright's Fixation Index ( $F$ from -0.41 to -0.59 ) (Fig. 2).

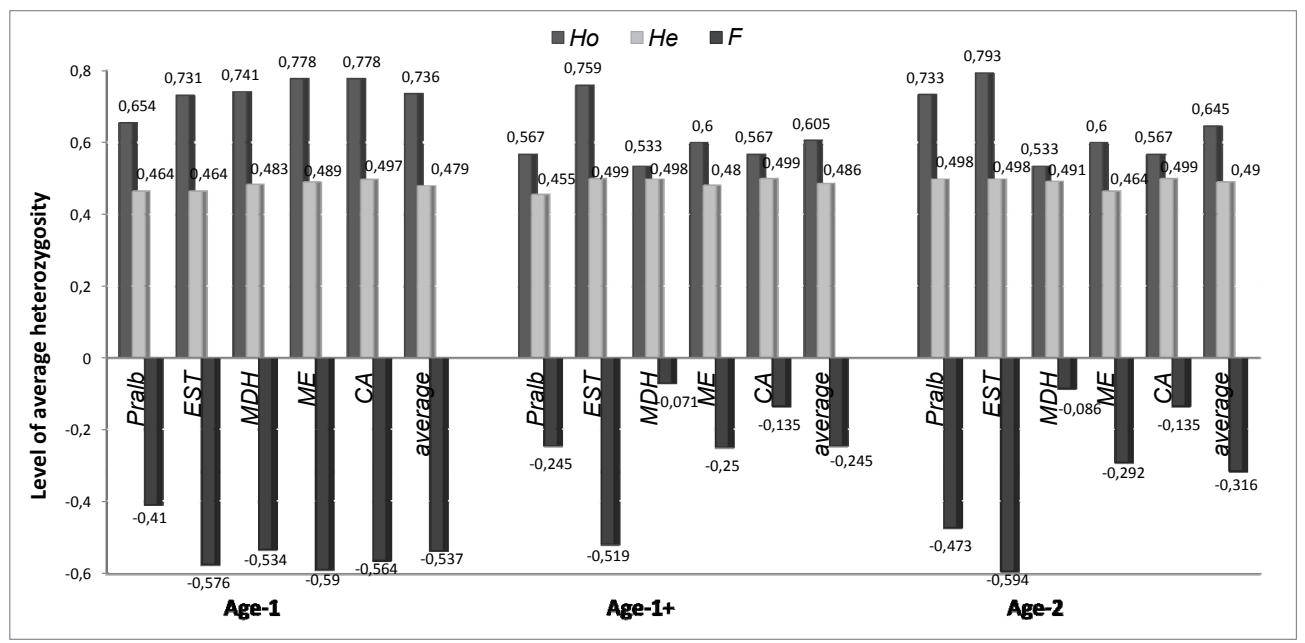

Fig. 2. The heterozygosity level and Wright's Fixation Index by geneticbiochemical markers in bighead carp

Note: the same as for Fig. 1 
In age-1+ bighead carp, $F$ values, which demonstrated the prevalence of $H_{o}$ over $H_{e}$, were detected for all loci: from insignificant $7.1 \%$ for $M D H$ to significantly higher $51.9 \%$ for $E S T$. We detected a significantly higher difference between observed and expected heterozygosity in age-2 bighead carp for Pralb (47.3\%) and EST (59.4\%) (Fig. 2).

In all examined fish groups, the established level of average heterozygosity by all loci was significantly higher than the theoretically calculated ones, in particular by $22.7-53.0 \%$ in silver carp and by $24.5-53.7 \%$ in bighead carp according to Fixation Index (Fig. 1, 2). The highest level of average heterozygosity was observed in both age1 silver (observed - 75.9\%, expected $-49.6 \%$ ) and bighead (observed $-73.6 \%$, expected $-47.9 \%$ ) carps. It is necessary to note that age-1 fish of both species have high heterogeneity and require a process of the genetic structure stabilization to be performed.

\section{CONCLUSION AND PERSPECTIVES OF FURTHER DEVELOPMENT}

The results of the studies of the genetic structures of multiple-age silver and bighead carps with the use of biochemical markers allow suggesting that age- 1 fish by population-genetic parameters differed from other age groups. High observed heterogeneity of the studied markers: from $66.7 \%$ to $88.9 \%$ in silver carp and from $65.4 \%$ to $77.8 \%$ in bighead carp as well as significant level of average heterozygosity of $75.9 \%$ in silver carp and $73.6 \%$ in bighead carp indicate on the necessity for maintaining the state of genetic equilibrium in age-1 fish populations.

The selection of fish according to the best phenotypic and culture-valuable characteristics during the selection works in the aquaculture facility contributed to the stabilization of the genetic structures by the heterogeneity level in age- 2 silver carp $\left(H_{O}\right.$ $=57.8 \% ; H_{e}=47.1 \%$ ).

For optimizing the selection process for further studies, it is necessary to control the level of heterozygosity in silver and bighead carp populations with the use molecular-genetic markers.

\section{BIBLIOGRAPHY}

1. Перспективи селекційно-племінної справи у рибництві України / В. В. Бех, I. I. Грициняк, О. О. Олексієнко [та ін.] // Вісник аграрної науки. - 2014. № 9. - С. $31-34$.

2. Організація селекційно-племінної роботи в рибництві / [Гринжевський М. В., Шерман I. М., Грициняк I. I. та ін.]; за ред. М. В. Гринжевського, I. М. Шермана. - К. : «Рибка моя», 2006. - 352 с.

3. Біологічне різноманіття сільськогосподарських тварин як об'єкт і предмет збереження генетичних ресурсів тваринництва України / Б. Є. Подоба, П. П. Джус, О. В. Сидоренко [та ін.] // Вісник Українського товариства генетиків і селекціонерів. - 2014. - Т. 12, № 1. - С. 58-64.

4. Тарасюк C. I. Молекулярно-генетичні дослідження в рибництві / С. I. Тарасюк, I. I. Грициняк. - К. : Аграрна наука, 2013. - 310 с.

5. Карнаухов Г. И. Альбумины белого и пестрого толстолобиков / Г.И. Карнаухов, В. Д. Василиади // Проблемы воспроизводства растительноядных рыб, их роль в аквакультуре: междунар. науч.-практ. конф. мат. - Краснодар : Здравствуйте, 2000. - С. 23-24. 
6. Карнаухов Г. И. Трансферрины белого и пестрого толстолобиков / Г. И. Карнаухов, В. Д. Василиади // Проблемы воспроизводства растительноядных рыб, их роль в аквакультуре : междунар. науч.-практ. конф. : мат. — Краснодар : Здравствуйте, 2000. - С. 22-23.

7. Семенов А. П. Биохимико-генетические исследования генеалогической разнокачественности ремонтно-маточного стада белого амура и белого толстолобика / А. П. Семенов, Е. В. Таразевич, В. Б. Сазанов // Вопросы рыбного хозяйства Беларуси. — 2006. — Вып. 22. - С. 36- 44.

8. Паюсова А. Н. Генетическая структура толстолобика, вывезенного из Вьетнама / А. Н. Паюсова, Т. Н. Целикова // Генетика. - 1993. — Т. 29, № 10. - C. 1685-1696.

9. Паюсова А. Н. Адаптивные изменения частот аллозимов у белого толстолобика в процессе его разведения и акклиматизации в СНГ / А. Н. Паюсова, Т. Н. Целикова // Генетика. — 1992. — Т. 28, № 9. - С. 105112.

10. Development of microsatellite DNA markers of silver carp (Hypophthalmichthys molitrix) and their cross-species application in bighead carp (Aristichthys nobilis) / M. J. Liao, G. P. Yang, X. C. Wang [et al.] // Molecular Ecology Notes. - 2007. - V. 7 (1). - P. 95-99.

11. Залоїло О. В. Аналіз генетичної структури білого та строкатого товстолоба 3 використанням мікросателітних маркерів / О. В. Залоїло, Н. Й. Тушницька // Сучасні проблеми практичної і теоретичної іхтіології : VII Міжнародна іхтіологічна наук.-практ. конф., 10-13 вер. 2014 р. : тези доп. - Херсон : Грінь Д.С., 2014. - С. 101-104.

12. Сравнительный анализ двух популяций белого толстолоба (Hypophthalmichthys molitrix) и карпа (Cyprinus carpio) с использованием микросателлитных ДНК-маркеров / И. С. Резникова, В. В. Степура, А. В. Шелев [и др.] // Фактори експериментальної еволюції організмів. 2010. - T. 9. - C. 64-69.

13. Борисенко Н. О. Особливості генетичної структури білого і строкатого товстолобиків / Н. О. Борисенко, Т. А. Нагорнюк, С. І. Тарасюк // Вісник аграрної науки Причорномор'я. - 2013. - Вип. 4 (76), т. 2, ч. 2. - С. 12-17.

14. Нагорнюк Т. А. Особливості генетичної структури різновікових груп білого товстолобика / Т. А. Нагорнюк // Вісник Сумського національного аграрного університету. - 2014. - Вип. 7 (26). - С. 51-54.

15. Davis B. J. Disc electrophoresis. II. Method and application to human serum proteins / B. J. Davis // Ann. N. Y. Acad. Sci. — 1964. — Vol. 121. - P. 404408.

16. Глазко В. И. Генетика изоферментов животных и растений / В. И. Глазко, И. А. Созинов. - К. : Урожай, 1993. - 528 с.

17. Генетика изоферментов / [Корочкин Л. И., Серов О. Л., Пудовник А. И. и др. - М. : Наука, 1977. - 275 с.

18. Wright S. Variability within and among natural populations. Vol. 4 / S. Wright. Chicago: Univ. Press, 1978. - P. 590.

19. Swofford D. L. Biosys-1: A Fortran program for the comprehensive analysis of electrophoretic data in population genetics and systematics / D. L. Swofford, R. B. Selander // J. Heredity. — 1981. - Vol. 72. - P. 281-283. 


\section{REFERENCES}

1. Bekh, V. V., Hrytsyniak, I. I., Oleksiienko, O. O., \& Osipenko, M. I. (2014). Perspektyvy selektsiino-pleminnoi spravy u rybnytstvi ukrainy. Visnyk ahrarnoi nauky, 9, 31-34.

2. Hrynzhevskyi, M. V., Sherman, I. M., Hrytsyniak, I. I., Vasylets, S. V., \& Tretiak, O. M. (2006). Orhanizatsiia selektsiino-pleminnoi roboty v rybnytstvi. Hrynzhevskyi, M. V. (Ed.), Sherman, I. M. (Ed.). Kyiv.

3. Podoba, B. Ye., Dzhus, P. P., Sydorenko, O. V., Vyshnevskyi, L. V., Huziev, I. V., \& Kuzebna, N. M. (2014). Biolohichne riznomanittia silskohospodarskykh tvaryn yak obiekt i predmet zberezhennia henetychnykh resursiv tvarynnytstva Ukrainy. Visnyk Ukrainskoho tovarystva henetykiv $i$ selektsioneriv, 12 (1), 58-64.

4. Tarasiuk, S. I., \& Hrytsyniak, I. I. (2013). Molekuliarno-henetychni doslidzhennia v rybnytstvi. Kyiv : Ahrarna nauka.

5. Karnaukhov, G. I., \& Vasiliadi, V. D. (2000). Al'buminy belogo i pestrogo tolstolobikov. Problemy vosproizvodstva rastitel'noyadnykh ryb, ikh rol' $v$ akvakul'ture: Mezhdunarodnoy nauchno-prakticheskoy konferentsii. Krasnodar : Zdravstvuyte, 23-24.

6. Karnaukhov, G. I., \& Vasiliadi, V. D. (2000). Transferriny belogo i pestrogo tolstolobikov. Problemy vosproizvodstva rastitel'noyadnykh ryb, ikh rol' $v$ akvakul'ture: Mezhdunarodnoy nauchno-prakticheskoy konferentsii. Krasnodar : Zdravstvuyte, 22-23.

7. Semenov, A. P., Tarazevich, E. V., \& Sazanov, V. B. (2006). Biokhimikogeneticheskie issledovaniya genealogicheskoy raznokachestvennosti remontnomatochnogo stada belogo amura $\mathrm{i}$ belogo tolstolobika. Voprosy rybnogo khozyaystva Belarusi, 22, 36-44.

8. Payusova, A. N., \& Tselikova, T. N. (1993). Geneticheskaya struktura tolstolobika, vyvezennogo iz V'etnama. Genetika, 29 (10), 1685-1696.

9. Payusova, A. N., \& Tselikova, T. N. (1992). Adaptivnye izmeneniya chastot allozimov u belogo tolstolobika $\mathrm{v}$ protsesse ego razvedeniya $\mathrm{i}$ akklimatizatsii $\mathrm{v}$ SNG. Genetika, 28 (9), 105-112.

10. Liao, M. J., Yang, G. P., Wang, X. C. et al. (2007). Development of microsatellite DNA markers of silver carp (Hypophthalmichthys molitrix) and their cross-species application in bighead carp (Aristichthys nobilis). Molecular Ecology Notes, 7 (1), 95-99.

11. Zaloilo, O. V., \& Tushnytska, N. Y. (2014). Analiz henetychnoi struktury biloho ta strokatoho tovstoloba z vykorystanniam mikrosatelitnykh markeriv. Suchasni problemy praktychnoi i teoretychnoi ikhtiolohii: VII Mizhnarodna ikhtiolohichna nauk.-praktych. konf. Kherson : Hrin D.S., 101-104.

12. Reznikova, I. S., Stepura, V. V., Shelev, A. V., Spiridonov, V. G., Mel'nichuk, S. D., \& Alymov, S. I. (2010). Sravnitel'nyy analiz dvukh populyatsiy belogo tolstoloba (Hypophthalmichthys molitrix) i karpa (Cyprinus carpio) $\mathrm{s}$ ispol'zovaniem mikrosatellitnykh DNK-markerov. Faktory eksperymental'noi evoliutsii organizmiv, 9, 64-69.

13. Borysenko, N. O., Nahorniuk, T. A., \& Tarasiuk, S. I. (2013). Osoblyvosti henetychnoi struktury biloho i strokatoho tovstolobykiv. Visnyk ahrarnoi nauky Prychornomoria, 4 (76), 2 (2), 12-17. 
14. Nahorniuk, T. A. (2014). Osoblyvosti henetychnoi struktury riznovikovykh hrup biloho tovstolobyka. Visnyk Sumskoho natsionalnoho ahrarnoho universytetu, 7 (26), 51-54.

15. Davis, B. J. (1964). Disc electrophoresis. II. Method and application to human serum proteins. Ann. N. Y. Acad. Sci., 121, 404-408.

16. Glazko, V. I., \& Sozinov, I. A. (1993). Genetika izofermentov zhivotnykh i rasteniy. Kiev : Urozhay.

17. Korochkin, L. I., Serov, O. L., Pudovnik, A. I., Aronshtam, A. A., Polyakova, E. V., Maletskiy, S. I., \& Borkin, L. V. (1977). Genetika izofermentov. Moskva : Nauka.

18. Wright, S. (1978). Variability within and among natural populations. Chicago : Univ. Press, 4, 590.

19. Swofford, D. L., \& Selander, R. B. (1981). Biosys-1: A Fortran program for the comprehensive analysis of electrophoretic data in population genetics and systematics $J$. Heredity, 72, 281-283.

\section{ГЕНЕТИЧНА СТРУКТУРА РІЗНОВІКОВИХ ГРУП БІЛОГО І СТРОКАТОГО ТОВСТОЛОБИКІВ ЛИМАНСЬКОГО ДВСРП}

T. А. Нагорнюк, achtaan@ukr.net, Інститут рибного господарства НААН, м. Київ

I. І. Грициняк, info@ifr.com.ua, Інститут рибного господарства НАAН, м. Київ

Н. О. Борисенко, $\underline{b}$ natalia@i.ua, Інститут рибного господарства НАAН, м. Київ

Мета. Вивчення особливостей генетичної структури різновікових груп білого $i$ строкатого товстолобиків Лиманського ДВСРП за використання генетико-біохімічних маркерів.

Методика. В дослідженнях використовували методи вертикального поліакриламідного та горизонтального крохмального електрофорезів з власними модифікаціями. Відбір зразків біологічного матеріалу та гістохімічне фарбування гелевих пластин проводили за загальноприйнятими методиками. Статистичне опрацювання експериментальних даних виконували з допомогою програми «Віоsys-1».

Результати. Виконано аналіз генетичної структури однорічок, дволіток і дворічок білого і строкатого товстолобиків за використання генетико-біохімічних маркерів - Рralb, EST, МDH, ME, СА. Показано особливості розподілу алельних частот і генотиповий склад локусів білкових систем. Встановлено високий рівень гетерозиготності за досліджуваними локусами у межах 66,7-88,9\% у білого та 65,4-77,8\% у строкатого товстолобиків однорічного віку. Спостерігалась значна перевага фрактичного рівня середньої гетерозиготності над очікуваним у однорічок білого ( $\left.H_{o}=75,9 \% ; H_{e}=49,6 \%\right)$ строкатого $\left(H_{o}=73,6 \% ; H_{e}=47,9 \%\right)$ товстолобиків, що вказує на необхідність стабілізації генетичної структури. Розрахований індекс фіксації Райта $F$ у різновікових груп показав перевагу фактичного рівня середньої гетерозиготності над очікуваним на 22,7-53\% у білого і на 24,553,7\% у строкатого товстолобиків. Відмічалась стабілізація генетичної структури за рівнем гетерогенності у дворічок білого товстолобика $\left(H_{o}=57,8 \% ; H_{e}=47,1 \%\right)$.

Наукова новизна. 3 використанням генетико-біохімічних маркерів вперше проведено оцінку генетичної структури та рівня гетерогенності племінних груп однорічок, дволіток, дворічок білого і строкатого товстолобиків, які вирощуються у Лиманському ДВСРП.

Практична значимість. Результати досліджень можуть бути використані у селекційно-племінній роботі при формуванні племінних стад товстолобиків з метою контролю рівня міжвидової генетичної мінливості. Отримані експериментальні дані аналізу 
генетичної структури різновікових груп білого та строкатого товстолобиків будуть використані для моніторингу змін генетичної структури у процесі їх адаптації до нових умов існування.

Ключові слова: білий товстолобик, строкатий товстолобик, однорічки, дволітки, дворічки, генетико-біохімічні маркери, генетична структура, алелі, генотип, гетерозиготність.

\section{ГЕНЕТИЧЕСКАЯ СТРУКТУРА РАЗНОВОЗРАСТНЫХ ГРУПП БЕЛОГО И ПЕСТРОГО ТОЛСТОЛОБИКОВ ЛИМАНСКОГО ГПСРП}

T. А. Нагорнюк, achtaan@ukr.net, Институт рыбного хозяйства НАAН, г. Киев

И. И. Грициняк, info@ifr.com.ua, Институт рыбного хозяйства НАAН, г. Киев

Н. А. Борисенко, b natalia@i.ua, Институт рыбного хозяйства НАAН, г. Киев

Цель. Изучение особенностей генетической структуры разновозрастных групп белого и пестрого толстолобиков Лиманского ГПСРП с использованием генетико-биохимических маркеров.

Методика. В исследованиях использовали методы вертикального полиакриламидного и горизонтального крахмального электрофорезов с собственными модификациями. Отбор образиов биологического материала и гистохимическое окрашивание гелевых пластин проводили по общепринятым методикам. Статистическую обработку экспериментальных данных выполняли с помощью программы «Biosys-1».

Результаты. Выполнен анализ генетической структуры годовиков, двухлеток и двухгодовиков белого и пестрого толстолобиков с использованием генетико-биохимических маркеров - Pralb, EST, MDH, ME, CA. Показаны особенности распределения аллельных частот и генотипический состав локусов белковых систем. Установлен высокий уровень гетерозиготности по исследованным локусам у годовиков в пределах 66,7-88,9\% у белого и 65,4-77,8\% у пестрого толстолобиков. Наблюдалось значительное преобладание фактического уровня средней гетерозиготности по сравнению с ожидаемым у годовиков белого $\left(H_{o}=75,9 \% ; H_{e}=49,6 \%\right)$ и пестрого $\left(H_{o}=73,6 \% ; H_{e}=47,9 \%\right)$ толстолобиков, что указывает на необходимость стабилизации генетической структуры. Рассчитанный индекс фиксации Райта $F$ у разновозрастных групп показал преобладание фрактического уровня средней гетерозиготности по сравнению с ожидаемым на 22,7-53\% у белого и на 24,5-53,7\% у пестрого толстолобиков. Отмечалась стабилизация генетической структуры по уровню гетерогенности у двухгодовиков белого толстолобика $\left(H_{o}=57,8 \% ; H_{e}=47,1 \%\right)$.

Научная новизна. При использовании генетико-биохимических маркеров впервые проведена оценка генетической структуры и уровня гетерогенности племенных групп годовиков, двухлеток, двухгодовиков белого и пестрого толстолобиков, которые выращиваются в Лиманском ГПСРП.

Практическая значимость. Результаты исследований могут быть использованы в селекционно-племенной работе при формировании племенных стад толстолобиков с целью контроля уровня межвидовой генетической изменчивости. Полученные экспериментальные данные анализа генетической структуры разновозрастных групп белого и пестрого толстолобиков будут использованы для мониторинга изменений генетической структуры в процессе их адаптации к новым условиям разведения.

Ключевые слова: белый толстолобик, пестрый толстолобик, годовики, двухлетки, двухгодовики, генетико-биохимические маркеры, генетическая структура, аллели, генотип, гетерозиготность.

60

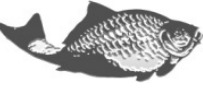

